\title{
Early open mitral valve surgery following arterial embolism
}

\author{
J.B. B O R M A N, G, MER IN, H. R O M A N O F F, \\ and H. MILW ID S K Y
}

\section{Department of Thoracic and Cardiovascular Surgery, Hadassah University Hospital, Jerusalem, Israel}

\begin{abstract}
A report is presented of nine patients who underwent early open mitral valve surgery after arterial embolism had occurred. Five of these patients suffered an early second arterial embolism before their mitral operation, an observation which stresses the risk inherent in delay of mitral valve surgery. The demonstration of atrial thrombi in four illustrates the potential danger of closed valvotomy techniques in such cases. Advanced pathological changes and severe stenosis of the mitral valve were found in all nine patients; valve replacement had to be done in three. All nine patients are alive and well after follow-up from 6 to 42 months. No further thromboembolic events have occurred after mitral valve surgery.
\end{abstract}

Peripheral arterial embolism is a common complication of mitral stenosis and is accepted by many as an indication for mitral commissurotomy (Glenn, Calabrese, Goodyear, Hume, and Stansel, 1969 ; Olesen and Baden, 1961). However, there is considerable dispute regarding the timing of the operation. Some authors (Ellis, Abelmann, and Harken, 1957 ; Glenn and McNeill, 1957) have recommended early cardiac surgery, whereas others take a more conservative approach (Taber and Lam, 1960 ; Kellogg, Liu, Fishman, and Larson, 1961 ; Szekely, 1964). Furthermore, the eventual surgical intervention may still be carried out using a c'osed valvotomy technique (Glenn et al., 1969 ; Deverall, Olley, Smith, Watson, and Whitaker, 1968).

We believe that delay of intervention and the use of 'closed' techniques are ill advised and even hazardous. Our experience, described below, leads us to recommend early, direct vision mitral valve surgery as soon as feasible after the embolic event.

\section{MATERIAL (Table)}

Nine patients have undergone 'open' mitral valve surgery following arterial embolism during the last three and a half years. Seven women and two men are included in this group. Their ages range from 19 to 60 years. Except for the two youngest, all had atrial fibrillation at the time of the embolic episodes. Six patients were without cardiac symptoms and mitral valve disease was not even suspected in four of them, the only call to medical attention being the acute anterial obstruction. One patient experienced three episodes of peripheral embolism before the diagnosis of mitral disease was proved. Two others suffered two embolic events before diagnosis of the mitral stenosis. In two patients the diagnosis was made at the time of the first arterial embolism, but they had another embolic event while awaiting cardiac surgery. Seven embolectomies were performed in five patients as the initial therapy (two patients had recurrent emboli necessitating repeat embolectomy).

All the peripheral embolectomies in this series were successful in restoring circulation to the affected limbs. Three patients had central retinal emboli and two suffered from cerebral emboli, one remaining with residual hemiplegia and speech difficulties. The shortest time elapsing between the patient's last embolism and the intracardiac surgery was four days and the longest time interval was two months. The main reason for the delay in some of these cases was the patient's hesitation to agree to an early heart operation. However, no patient refused mitral valve surgery subsequent to a second arterial embolism. In one patient, who was asymptomatic before the embolism, mitral valve surgery had to be postponed for 34 days due to the onset of subacute bacterial endocarditis and later pulmonary oedema. Six patients underwent mitral valve surgery within three weeks of the embolic episode and during the same hospital stay.

A tenth patient should be included in this group: a 45-year-old quarry labourer was successfully operated on for aortic saddle embolus. Mitral stenosis and atrial fibrillation were discovered for the first time. Ten days after the embolectomy right heart catheterization revealed severe pulmonary hypertension $(85 / 40 \mathrm{~mm} . \mathrm{Hg})$ and a markedly raised capillary mean pressure $(40 \mathrm{~mm}$. $\mathrm{Hg})$. While awaiting 
T A B L E

\begin{tabular}{|c|c|c|c|c|c|c|c|c|c|}
\hline No. & Sex & Age & Rhythm & Site of Embolus & $\begin{array}{l}\text { Interval to } \\
\text { Cardiac } \\
\text { Surgery }\end{array}$ & Operative Findings & $\begin{array}{l}\text { Operative } \\
\text { Procedure }\end{array}$ & Follow-up & $\begin{array}{l}\text { Post-op. } \\
\text { Embolus }\end{array}$ \\
\hline 1 & $\mathrm{~F}$ & 24 & Sinus & $\begin{array}{l}\text { R. central } \\
\text { Retinal }\end{array}$ & 38 days & $\begin{array}{l}\text { Mitral stenosis } \\
\text { Valvular orifice } 10 \mathrm{~mm} .\end{array}$ & $\begin{array}{l}\text { Mitral } \\
\text { valve } \\
\text { replacement }\end{array}$ & $\begin{array}{l}38 \text { months } \\
\text { Alive and well }\end{array}$ & No \\
\hline 2 & $F$ & 32 & A.F. & $\begin{array}{l}\text { Bilat. femoral } \\
\text { R. femoral }\end{array}$ & $\begin{array}{r}10 \text { days } \\
4 \text { days }\end{array}$ & $\begin{array}{l}\text { Mitral stenosis } \\
\text { Valvular orifice } 8 \mathrm{~mm} \text {. }\end{array}$ & Valvotomy & $\begin{array}{l}27 \text { months } \\
\text { Alive and well }\end{array}$ & No \\
\hline 3 & $\mathrm{~F}$ & 19 & Sinus & L. retinal & 60 days & $\begin{array}{l}\text { Mitral stenosis } \\
\text { Valvular orifice } 12 \mathrm{~mm} \text {. }\end{array}$ & Valvotomy & $\begin{array}{l}12 \text { months } \\
\text { Alive and well }\end{array}$ & No \\
\hline 4 & $\mathrm{~F}$ & 50 & A.F. & $\begin{array}{l}\text { Aortic bifurcation } \\
\text { (saddle) }\end{array}$ & 60 days & $\begin{array}{l}\text { Mitral stenosis } \\
\text { Valvular orifice } 8-10 \mathrm{~mm} \text {. }\end{array}$ & Valvotomy & $\begin{array}{l}11 \text { months } \\
\text { Alive and well }\end{array}$ & No \\
\hline 5 & $\mathbf{M}$ & 48 & A.F. & $\begin{array}{l}\mathbf{R} \text {. brachial } \\
\mathbf{R} \text {. brachial }\end{array}$ & $\begin{array}{l}60 \text { days } \\
20 \text { days }\end{array}$ & $\begin{array}{l}\text { Mitral stenosis } \\
\text { Valvular orifice } 10 \mathrm{~mm} \text {. }\end{array}$ & $\begin{array}{l}\text { Mitral } \\
\quad \text { valve } \\
\text { replacement }\end{array}$ & $\begin{array}{l}9 \text { months } \\
\text { Alive and well }\end{array}$ & No \\
\hline 6 & $\mathbf{M}$ & 35 & A.F. & $\begin{array}{l}\text { Cerebral } \\
\text { Cerebral }\end{array}$ & $\begin{array}{l}4 \text { months } \\
14 \text { days }\end{array}$ & $\begin{array}{l}\text { Mitral stenosis } \\
\text { Valvular orifice } 8 \mathrm{~mm} \text {. } \\
\text { Free and adherent thrombus }\end{array}$ & $\begin{array}{l}\text { Mitral } \\
\text { valve } \\
\text { replacement }\end{array}$ & $\begin{array}{l}9 \text { months } \\
\text { Alive and well }\end{array}$ & No \\
\hline 7 & $\mathbf{F}$ & 59 & A.F. & $\begin{array}{l}\text { R. femoral } \\
\text { L. femoral } \\
\text { R. central retinal }\end{array}$ & $\begin{array}{l}3 \text { months } \\
3 \text { months } \\
14 \text { days }\end{array}$ & $\begin{array}{l}\text { Mitral stenosis } \\
\text { Valvular orifice } 12 \mathrm{~mm} \text {. } \\
\text { Free and adherent thrombus }\end{array}$ & Valvotomy & $\begin{array}{l}6 \text { months } \\
\text { Alive and well }\end{array}$ & No \\
\hline 8 & $\mathrm{~F}$ & 60 & A.F. & $\begin{array}{l}\text { Aortic bifurcation } \\
\text { (saddle) }\end{array}$ & 17 days & $\begin{array}{l}\text { Mitral stenosis } \\
\text { Valvular orifice } 6 \mathrm{~mm} \text {. } \\
\text { Free and adherent thrombus }\end{array}$ & Valvotomy & $\begin{array}{l}6 \text { months } \\
\text { Alive and well }\end{array}$ & No \\
\hline 9 & $\mathbf{F}$ & 51 & A.F. & R. femoral & 10 days & $\begin{array}{l}\text { Mitral stenosis } \\
\text { Valvular orifice } 8 \mathrm{~mm} \text {. } \\
\text { Free and adherent thrombus }\end{array}$ & Valvotomy & $\begin{array}{l}6 \text { months } \\
\text { Alive and well }\end{array}$ & No \\
\hline
\end{tabular}

A.F. = Atrial fibrillation

his turn for 'open' heart surgery in the hospital he died suddenly, four days after the catheterization. No necropsy permission was granted but the very sudden death is most suggestive of coronary embolism.

\section{TECHNICAL CONSIDERATIONS}

All patients were operated on with extracorporeal circulation maintained by the Rygg-Kyvsgaard disposable bubble oxygenator. ${ }^{1}$ The priming solution was reconstituted ACD blood and Ringer's lactate. Moderate hypothermia to $30^{\circ} \mathrm{C}$. was used.

The heart was approached via a midline sternotomy incision and was very carefully manipulated, special care being taken to avoid contact with the left atrium and its appendage before bypass. After opening the left atrium in the interatrial groove, its interior and the appendage were explored and thrombi were completely removed when present. Only after ligation of the appendage at its base and repeat examination of the left atrial cavity for free clots was attention turned to the mitral valve and the appropriate surgery carried out.

\section{INTRA-OPERATIVE FINDINGS AND RESULTS}

The left atrial appendage was found to contain both free and adherent thrombi in four patients. All nine patients had 'pure' mitral stenosis; the largest orifice had a maximum diameter of $12 \mathrm{~mm}$. and the smallest $6 \mathrm{~mm}$. In seven patients the stenosis was recorded

\footnotetext{
${ }^{1}$ Polystan, Copenhagen
}

as severe with maximum orifice diameter less than $10 \mathrm{~mm}$. An initial attempt at commissurotomy was $\frac{0}{\mathbb{Q}}$ made in all cases and was successful in six. In three $\varrho$ patients the functional result of the valvotomy was $\overrightarrow{\vec{O}}$ considered to be unsatisfactory and the mitral valve 3 was replaced with a Kay-Shiley disc prosthesis.

No mortality occurred in this series. None of these? patients showed evidence of intra-operative or postoperative arterial embolism during a follow-up periodo ranging from six months to three and a half years. All patients have returned to their former employ-:ment and even those who denied pre-operative 3 . cardiac symptoms admitted to improvement in theiro condition following heart surgery.

\section{COMMENT}

Closed mitral valvotomy is considered by many as the operation of choice in selected cases of iso- $N$ lated pure mitral stenosis with no evidence of n valve calcification. However, in our opinion, in N the presence of recent arterial embolism the use $\omega$ of the open-heart technique is essential in order to prevent the mishap of intra-operative arteriale embolism due to dislodgement of atrial or valvular thrombus. Before the introduction of extracorporeal circulation, we personally witnessedintra-operative aortic saddle embolism in threed patients, and this unfortunate experience has been? shared by others. Ellis and Harken (1961) found ${ }^{Q}$ that 32 out of 260 patients who gave a history? of pre-operative arterial embolism suffered an 
intra-operative embo'ism. Deverall et al. (1968) reported systemic embolism as the cause of intraoperative death in 9 patients out of a series of 298 mitral valvotomies. Four out of the nine patients in our series were found to have thrombus in the atrial cavity and/or the appendage at the time of surgery. Closed commissurotomy may have resulted in a catastrophe. In order to minimize handling of the left atrium and its appendage it is recommended that the surgical approach be via a midline sternotomy or a right thoraco. tomy which also enables thorough inspection of the left atrial cavity.

Our experience suggests that the occurrence of peripheral arterial embolism is an indication of advanced mitral valve pathology even in patients without cardiac complaints.

The operative findings in every patient proved to be tight mitral stenosis. Furthermore, in one patient who had been asymptomatic till unilateral blindness due to a central retinal arterial embolus occurred, the onset of pulmonary oedema the night before scheduled surgery is evidence of the severity of the mitra! stenosis. The very fact that valve replacement was necessary in three patients stresses the far advanced pathological changes of the mitral valve.

Five of the nine patients had recurrent emboli shortly before intracardiac surgery, whereas another patient succumbed to his second arterial embolism a few days before scheduled surgery. According to Jacobs (1959), arterial embolism was fatal in $18 \%$ of the patients suffering from mitral stenosis, and in another $5 \%$ arterial embolism was found to be contributory to death. Glenn et al. (1969) found that $31.8 \%$ of their fatalities were attributable to systemic embolus. Furthermore, Darling, Austen, and Linton (1967) found the incidence of recurrent emboli in rheumatic heart disease to be $56.2 \%$. Therefore, every effort should be made to proceed with early open-heart surgery during the patient's hospitalization for the first embolus. The only possible exception to this rule is the patient with massive hemiplegia following cerebral embolism.

Our reluctance to delay surgery in cases of arterial embolism due to clinically proven isolated pure mitral stenosis would prompt us to operate without cardiac catheterization if this examination involves unjustifiable procrastination.

In this series anticoaguant therapy was only used following mitral valve replacement. None of the patients suffered post-operative embolization, despite recurrent embolic episodes, in the majority, prior to the mitral valve surgery.

\section{REFERENCES}

Darling, R. C., Austen, W. G., and Linton, R. R. (1967). Arteria embolism. Surg. Gynec. Obstet., 124, 105.

Deverall, P. B., Olley, P. M., Smith, D. R., Watson, D. A., and Whitaker, W. (1968). Incidence of systemic embolism before and af ier mitral valvotomy. Thorax, 23, 530 .

Ellis, L. B., Abslmann, W. H., and Harken, D. E. (1957). Selection of pitients for mitral and aortic valvuloplasty. Circulation, $15,924$.

and Harken, D. E. (1961). Arterial embolization in relation to mitral valvuloplasty. Amer Heart J., 62, 611 .

Glenn, W. W. L., Calabrese, C., Goodyear, A. V. N., Hume, M., and Stansel, H. C. (1969). Mitral valvotomy II. Operative results after closed valvulotomy. A report of 500 cajes. Amer J. Surg., $117,493$.

_ and McNeill, T. M. (1957). Aortic embolism complicating mitral stenosis, with particular reference to emergency valvulotomy before embolectomy. New Engl. J. Med., 256, 295.

Jacobs, A. L. (1959). Arterial Embolism in the Limbs. p. 17. Livingstone, Edinburgh and London.

Kellogg, F., Liu, C. K., Fishman, I. W., and Larson, R. (1961). Systemic and pulmonary emboli before and after mitral commissurotomy. Circulation, 24, 263.

Olesen, K. H., and Baden, H. (1961). Survival in mitral stenosis with and without operation: a nine year follow-up. Acta chir. scand., Suppl. 283, 116.

Szekely, P. (1964). Systemic embolism and anticoagulant prophylaxis in rheumatic heart disease. Brit. med. J., 1, 1209.

Taber, R. E., and Lam, C. R. (1960). Significance of atrial fibrillation and arterial embclization in rheumatic mitral valve disease. Circulation, 22, 821 . 